\title{
Flow in Business Simulation Games: Comparison between Online and Face- to-Face MBA
}

\author{
J.B. (Joo Baek) Kim \\ Worcester Polytechnic Institute \\ jkim3@wpi.edu
}

\author{
Edward F. Watson III \\ Louisiana State University \\ ewatson@1su.edu
}

\begin{abstract}
This study explores the role of flow and its relationship with other elements of Business Simulation Games (BSGs) used in different MBA course delivery methods, namely online vs.face-to-face $(F 2 F)$. We collect level of flow and other game behavioral variables from young professionals enrolled in an MBA Technology and Operations Management course. We analyze the data with oneway ANOVA to explore flow measures across different course delivery methods. The findings show there exist differences in flow level and performance measures between online and $F 2 F$ formats.
\end{abstract}

\section{Introduction}

For many years, organizations have pursued various approaches to enhance the effectiveness of training and education for their employees to help them perform to their fullest potential. Business simulation games (BSGs) provide a good opportunity for learners to develop risk-free decision making experiences and to improve their decision-making skills by trial-anderror role playing. BSGs are used increasingly for these purposes.

There are many different types of skills that corporations expect their employees to have, which include job-specific skills, people skills, organizational skills, communication skills, and strategy-making skills [39]. BSGs are effective as learning through trial-anderror "discovery" that eventually leads to greater levels of engagement and higher retention rates. Prensky [45] identified the following situations where game-based learning is beneficial: (1) Dry, technical, boring subject matter; (2) Complex subject matter that is difficult to understand or transmit; (3) Subject matter that is difficult to articulate to an audience; (4) Assessment and certification material that is difficult to learn; (5) Analysis that involves sophisticated "What if?" inquiry and (6) Strategic planning, analysis and communication.

Learning by doing, or experiencing, is one of the most effective ways of learning [24]. AACSB (Association to Advance Collegiate Schools of Business) emphasizes the importance of incorporating effective and practical learning approaches into the MBA experience, including real-world experience, critical thinking, communication skills, global awareness, and integration skills [1][14]. In addition, national recruiters have identified important skill sets for new graduates to including dealing with ambiguity and uncertainty. This level of learning can be enhanced by working within complex (simulated) environments that have challenging problems to solve.

It is also worth noting that business education often targets adult learners. Adult learners have already developed a certain amount of knowledge and experience in their own discipline. They are likely to learn new things based on their individual needs. They are known to learn faster by trial-and-error based on their existing knowledge [28]. Knowles [33] characterized the traits of adult learners as follows: (1) Desire to rapidly apply and test their learning; (2) Need to pull from real-life experience as a learning resource; (3) Requirement to self-manage, plan, and individually execute their learning activities; (4) Desire for a reallife-centric approach to learning new information and solving problems.

Moreover, today's business environment is very complex and dynamic so the traditional linear type learning methods (e.g., reading materials, listening to lectures, and taking notes) are not enough to prepare students for the modern, global business environment [49]. It is important for business students to understand how to gather the necessary information from a complex situation and derive actionable intelligence, evaluate possible solutions, and then implement a decision in a certain context in order to determine its effectiveness. This kind of problem-finding and solving skill is not easy to develop with traditional learning methods. Instead, providing student with a real world-like experience in a specific context, and 
letting them find a workable solution by trial-and-error is more effective for this purpose.

On the other hand, with the explosion of Internet use and with advances in information and learning technology, the potential of online education is tremendous. It is estimated that enrollment in online business education programs is steady or increasing in over $80 \%$ of available online programs around the U.S. [2]. However, online programs have struggled for many reasons such as: resource constraints, inappropriate technologies, lack of student services, instructors' poor understanding of new delivery format, and other reasons [3].

Numerous studies have attempted to determine how to enhance the effectiveness of online business education but conclusions are mixed, at best, to date [3]. Among various factors influencing the effectiveness of online business education, contentand interaction-related factors are the most significant [52]. Online course content must be up-to-date, and must motivate the leaner [16][29]. Studies found that course content affects the quality of the learners' perceived learning experience as well as the satisfaction with online courses [44][4]. However, due to the differences in timeframe, delivery medium, and limited interactions in online courses than traditional face-to-face format, course content in online business education needs to be perhaps more carefully considered and determined.

Interaction is another significant factor that determines the quality of the courses in online business education. AACSB recognizes the importance of interaction in the learning process [1]. Interaction may include an instructor providing feedback on students' activities and performance levels, answering questions, as well as peer-to-peer student interactions such as discussions. In the online learning environment, discussion forums and/or chat rooms are popular as an effective way to foster the students' sense of connectedness to the instructor and their classmates [54]. Nonetheless, online business educators still struggle with how to most effectively facilitate student interactions due to the long distance challenges of isolation, time-differences, internet connectivity, and lack of face-to-face connectivity.

Students in online business education want highquality course content as much as the F2F environment. BSGs are one of the most effective ways of fulfilling this requirement; in a sense, they are developed by experts in the subject area as well as designed to engage the learners in activities which force them to learn by doing. Engagement is believed to be associated with learning outcomes including performance, satisfaction, and retention [6].
Nevertheless, not all BSGs provide effective learning experiences. One of the main factors of a game that makes its players engage is flow. Like other game playing, interactions with BSGs can lead to enjoyable experience for the player [9]. When there is an appropriate balance of player's skill and challenge in the game, players may feel high levels of immersion in the game, which often leads players' loss of time/place and intrinsically rewarding experience [12]. First suggested by Csikszwntmihalyi [11], flow is believed to be a hallmark of high engagement in an activity, which is often associated with increased time on task, deeper learning experience, eventually resulting in better performance [27][8].

Understanding flow should be an essential part of the effective design and implementation of BSGs. However, little knowledge has been gained with regard to the status and role of flow in different business education delivery formats, i.e., online vs. face-to-face. Due to the different learning environments available and to the perceptions of different types of learners, flow may have a different impact on different learners, and in different delivery formats. Understanding the role of flow in different environments and the relationships with other important factors such as students' performance should help to shed light on the effective application of BSGs in both online and faceto-face business education. Hence, in this study we explore the difference between online and face-to-face MBA courses especially in terms of flow, effort, and performance in business simulation game playing.

\section{Theoretical Backgrounds}

\subsection{Business Simulation Games (BSGs)}

Simulation games are widely used in game-based learning. Simply stated, simulation games are simulations that include game aspects [25]. More specifically, they can be defined as "an exercise that has basic characteristics of both games and simulation... undertaken by players whose actions are constrained by a set of explicit rules particular to that game and by a predetermined end point (p. 3, [15])"

Modern business games leverage concepts from military war games, operations research, computer science, and education theory [55]. During World Wars I and II, complex war games were developed and used for military purpose. After the wars, many military personnel and resources influenced game development in the business world as they saw many opportunities to apply war simulation to business education and trainings. The combination of experience-based 
learning and technological advancements led to the rapid development of many BSGs.

Gentry [24] claimed that computer-assisted instruction (which includes business simulation games) are effective instruction method to provide experiential learning to business students for the ability to focus on content, high level control, feedback, more intense activity, and self-pacing. Game-based learning is also good for students to remember what they learned for a long time.

Games provide business students the opportunity to experience complex situations that require them to understand multiple business concepts simultaneously. For example, business strategy games require game participants to consider many different business parts simultaneously, such as marketing, finance, and supply chain, so participants can be trained to make better "integrated" decisions based on various perspectives. Keys and Wells [31] pointed out that there are three factors necessary for effective management learning; dissemination of content, opportunities for experience, and feedback. Business simulation games fulfill the three requirements because, content is self-discovered, experience is rich, and feedback from simulated reality is more helpful than reality [35]. Faria and Wellington [20] identified various advantages of business simulation games to students and teachers. Those perceived advantages include: (1) Experiential learning; (2) Integration of different functional areas; (3) Application of theory; (4) Demonstration of the consequences of decisions; (5) Teamwork and involvement; (6) Interactive/dynamic exercises; (7) Realism; (8) Exposure to business competition; and (9) Fun, interest and motivation.

\subsection{Flow in Business Simulation Games}

Educational games engage and motivate learners by sustaining more challenging learning tasks and less instructional involvement [22][43][37][36][48][23] [50]. Previous studies revealed that computer-based games elicit more student engagement than traditional classroom activities [37][36][48]. One plausible explanation of the games' engaging characteristics is "flow" theory [11][12]. Flow is the psychological state in which a person is fully immersed in an activity balancing both ability and challenge [11]. Csikszentmihalyi [13] claimed that flow experience "seems to occur only when a person is actively engaged in some form of clearly specified interaction with the environment (p. 43)". When this state occurs, a player would lose the consciousness of time and/or other tasks with a feeling of high level enjoyment and immersion. The key to the flow experience is an optimal balance between perceived skills and challenges [10]. If the level of challenge becomes too high where skill level is consistent, one would feel anxiety. If the level of skills becomes too high where challenge level is the same, one would feel boredom. Only when the two perceptions keep staying in a balanced area, would one feel flow.

Csikszentmihalyi [11] identifies many dimensions of flow. Among them, the following eight are considered to be the main components of flow: clear goals; balanced challenge-skill level; immediate feedback; sense of control; action awareness merging; loss of self-consciousness; concentration; autotelic experience; and time distortion [32]. Among them, concentration, autotelic experience, and time distortion can be classified into the aftereffect of one's flow experience, which we will focus on in this study.

Many researchers found that flow theory can explain the intrinsic motivation of gamers to a large extent [30][40][38][51][46]. Games are good at facilitating flow experiences through characteristics such as interaction and challenge [18]. Hoffman and Nadelson [26] claimed that "gaming promotes intrinsic motivation, positive affect, and many aspects of the flow experience (p.248)". By providing flow experience, educational games can enable learners to stay engaged in, and focused on, the subject matter. Flow has been considered a useful construct to describe and measure how much a person is intrinsically engaged in an activity. Much of the video game literature and education literature has addressed flow and has used it to measure engagement of players or learners [9][47][53][5]. In prior studies, a positive relationship between flow and learning was identified especially in learning in technology environments [8][34][32].

Previous games-related studies have considered that flow is a major factor that can explain the process of learning through games [8] [32][34][42][53]. However, not much research has been conducted in the higher education environment, especially in the Business Education context. Hence, we seek to gain a better understanding of the role of flow in BSGs in the contexts of online and F2F MBA courses through this study.

\section{Methodology}

In this study, we measure and compare flow experience and other game associated behaviors of students enrolled in different MBA program formats who play three BSGs in the Technology and Operations Management course. The BSGs are designed to train players with specific topics, namely, project management, service operations management, and global supply chain management, respectively. 
Each BSG is specialized to offer players with opportunities to learn the concepts and develop skills associated with the topic. More details and screenshots of the BSGs used for this study are available in Table 1 and Appendix.

Table 1. Description of BSGs

\begin{tabular}{|c|c|c|l|l|l|}
\hline BSG & Context & Role & \multicolumn{1}{c|}{$\begin{array}{c}\text { Learning Objectives } \\
\text { Decisions }\end{array}$} \\
\hline BSG 1 & $\begin{array}{c}\text { High Tech } \\
\text { Industry }\end{array}$ & $\begin{array}{c}\text { IT Project } \\
\text { Manager }\end{array}$ & $\begin{array}{l}\text { - Understand how to effectively manage project scope, resources, and } \\
\text { schedule to improve project outcomes } \\
\text { - Understand how to design teams and how to manage team morale, } \\
\text { productivity and work quality to improve project outcome }\end{array}$ & $\begin{array}{l}\text { Schedule, } \\
\text { Scope, Budget, } \\
\text { Team }\end{array}$ \\
\hline BSG 2 & Restaurant & $\begin{array}{c}\text { Restaurant } \\
\text { Manager }\end{array}$ & $\begin{array}{l}\text { - Understand how to effectively manage capacity constraints, dining } \\
\text { schedules, service delivery and customer experience, under conditions } \\
\text { of market uncertainty, to maximize evening profit in a restaurant. }\end{array}$ & $\begin{array}{l}\text { Restaurant } \\
\text { layout and } \\
\text { operating } \\
\text { parameters }\end{array}$ \\
\hline BSG 3 & $\begin{array}{c}\text { Global } \\
\text { Mobile } \\
\text { Phone } \\
\text { Supply } \\
\text { Chain }\end{array}$ & $\begin{array}{c}\text { Supply } \\
\text { Chain } \\
\text { Manager }\end{array}$ & $\begin{array}{l}\text { - Understand how better manage key supply chain decision factors } \\
\text { such as product design feature selection, production scheduling and } \\
\text { sourcing to improve supply chain performance. } \\
\text { - Understand how to design more flexible supply chains and how to } \\
\text { most effectively leverage imperfect information from the market and } \\
\text { from superiors and peers, to improve operating performance. }\end{array}$ & $\begin{array}{l}\text { Sourcing, } \\
\text { planning, } \\
\text { execution }\end{array}$ \\
\hline
\end{tabular}

\subsection{Data Collection}

The MBA students enrolled in a technology and operations management course at a large state University in the U.S. played the BSGs as a part of the required course activities. After playing BSGs, overall 191 students from various MBA program formats including traditional full-time MBA program (face-toface), professional MBA program (face-to-face) and the professional online MBA program took a survey measuring various players' perceptions including flow experience with game play from Spring 2014 to Spring 2017. Table 2 summarizes the data collected.

Table 2. Classes and Survey Participants

\begin{tabular}{|c|c|c|c|c|}
\hline Program & Format & Term & $\begin{array}{l}\text { No. of } \\
\text { Players }\end{array}$ & $\begin{array}{c}\text { Online/ } \\
\text { F2F }\end{array}$ \\
\hline \multirow[t]{2}{*}{$\begin{array}{l}\text { Full-time } \\
\text { MBA }\end{array}$} & \multirow{2}{*}{$\begin{array}{l}\text { Traditional } \\
\text { face-to-face } \\
\text { day classes }\end{array}$} & $\begin{array}{c}\text { Spring } \\
2014\end{array}$ & 48 & \multirow{3}{*}{$\begin{array}{l}\text { F2F } \\
\text { (total } \\
140)\end{array}$} \\
\hline & & $\begin{array}{l}\text { Spring } \\
2015\end{array}$ & 52 & \\
\hline $\begin{array}{l}\text { Professio } \\
\text { nal MBA }\end{array}$ & $\begin{array}{l}\text { Face-to-face } \\
\text { evening } \\
\text { classes }\end{array}$ & $\begin{array}{c}\text { Fall } \\
2014\end{array}$ & 40 & \\
\hline \multirow[t]{3}{*}{$\begin{array}{l}\text { Online } \\
\text { MBA }\end{array}$} & \multirow{3}{*}{$\begin{array}{l}100 \% \text { online, } \\
\text { no face-to- } \\
\text { face meetings }\end{array}$} & $\begin{array}{c}\text { Summer } \\
2014 \\
\end{array}$ & 16 & \multirow{3}{*}{$\begin{array}{c}\text { Online } \\
\text { (total } \\
53 \text { ) }\end{array}$} \\
\hline & & $\begin{array}{c}\text { Spring } \\
2015\end{array}$ & 16 & \\
\hline & & $\begin{array}{c}\text { Spring } \\
2017\end{array}$ & 21 & \\
\hline \multicolumn{3}{|l|}{ Total } & 193 & \\
\hline
\end{tabular}

Prior studies used flow to measure the degree of engagement in game playing [5][42]. Flow is defined as an optimal state where a person is intrinsically motivated with intense concentration and enjoyment [8]. Csikszwntmihalyi [11] claimed that flow is the holistic sensation present when people act with total involvement. He suggests that not all flow dimensions are necessary for the flow experience. Moreover, as mentioned in the previous section, some of the dimensions may be considered precondition to the flow experience. Given that the main purpose of this study is to determine the extent to which MBA students from different course delivery formats have different flow levels, we believe it is better to focus on the outcome of the flow experience of the students who go through BSGs in their course. Hence, we used three items each with a 5-point Likert scale to measure flow experience from players mainly focusing on the flow dimensions of time distortion, concentration, and autotelic experience, as follows: (1) When playing the simulation game, I lost track of time (time distortion); (2) When playing the simulation game, I was not aware of any noises (concentration); (3) When playing the simulation game, I was so absorbed in the game that I often forgot about my other responsibilities (autotelic experience).

The behavioral outcomes (e.g., game efforts and game performance) data were also collected after they finished game playing. To this end, we measured the number of runs a player played in each BSG as the game effort, and the best score achieved in each BSG as the game performance variable. However, because each BSG has different game characteristics, the specific measurement methods of the behavioral outcomes are slightly different per BSG. For example, BSG 1 is composed of three scenarios with different 
settings and difficulties, so we collected the total number of game runs as the game effort and the average of the best scores from three scenarios that a player gained as the game performance. BSG 2 is composed of six scenarios with accumulative skill learning process. Hence we collected only the number of runs of the final scenarios as the game effort and the best score of the final scenario as the game performance. Since BSG 3 has only a single setting but takes substantial time to complete (usually 30 minutes to 1 hour per run), we capped the attempts to at most three runs. We instead collect the perceived time the players spent playing the BSG as a part of the survey and use as proxy of the game effort. Table 3 presents the summary of flow and other behavioral game variables measured from the three BSGs.

Table 3. Variable Summary

\begin{tabular}{|c|c|c|c|c|c|c|c|c|c|c|}
\hline \multirow[t]{2}{*}{ Format } & \multirow[t]{2}{*}{$\mathrm{N}$} & \multicolumn{3}{|c|}{ BSG 1} & \multicolumn{3}{|c|}{ BSG 2} & \multicolumn{3}{|c|}{ BSG 3} \\
\hline & & $\begin{array}{c}\text { Flow } \\
\text { Mean } \\
(\mathrm{SD})\end{array}$ & $\begin{array}{c}\text { Game } \\
\text { effort } \\
\text { Mean (SD) }\end{array}$ & $\begin{array}{c}\text { Game } \\
\text { Perform. } \\
\text { Mean (SD) }\end{array}$ & $\begin{array}{c}\text { Flow } \\
\text { Mean } \\
(\mathrm{SD})\end{array}$ & $\begin{array}{c}\text { Game } \\
\text { effort } \\
\text { Mean (SD) }\end{array}$ & $\begin{array}{c}\text { Game } \\
\text { Perform. } \\
\text { Mean (SD) }\end{array}$ & $\begin{array}{l}\text { Flow } \\
\text { Mean } \\
(\mathrm{SD})\end{array}$ & $\begin{array}{c}\text { Game } \\
\text { effort } \\
\text { Mean (SD) }\end{array}$ & $\begin{array}{c}\text { Game } \\
\text { Perform. } \\
\text { Mean (SD) }\end{array}$ \\
\hline $\mathrm{F} 2 \mathrm{~F}$ & 139 & $\begin{array}{c}2.89 \\
(0.84) \\
\end{array}$ & $\begin{array}{c}74.04 \\
(55.67) \\
\end{array}$ & $\begin{array}{l}793.41 \\
(68.22) \\
\end{array}$ & $\begin{array}{c}2.75 \\
(0.88) \\
\end{array}$ & $\begin{array}{c}86.17 \\
(65.78) \\
\end{array}$ & $\begin{array}{r}681.99 \\
(60.42) \\
\end{array}$ & $\begin{array}{c}2.75 \\
(0.91) \\
\end{array}$ & $\begin{array}{c}3.67 \\
(2.25) \\
\end{array}$ & $\begin{array}{l}94.44 \\
(3.15) \\
\end{array}$ \\
\hline Online & 53 & $\begin{array}{c}3.47 \\
(0.87) \\
\end{array}$ & $\begin{array}{c}77.49 \\
(65.22) \\
\end{array}$ & $\begin{array}{c}756.05 \\
(120.84) \\
\end{array}$ & $\begin{array}{c}3.44 \\
(0.76) \\
\end{array}$ & $\begin{array}{c}75.69 \\
(61.14) \\
\end{array}$ & $\begin{array}{l}652.56 \\
(81.68) \\
\end{array}$ & $\begin{array}{c}3.51 \\
(0.86) \\
\end{array}$ & $\begin{array}{c}4.69 \\
(2.44) \\
\end{array}$ & $\begin{array}{l}96.71 \\
(2.53) \\
\end{array}$ \\
\hline Total & 192 & $\begin{array}{c}3.06 \\
(0.89)\end{array}$ & $\begin{array}{c}74.99 \\
(58.30)\end{array}$ & $\begin{array}{l}783.10 \\
(87.28)\end{array}$ & $\begin{array}{c}2.95 \\
(0.90)\end{array}$ & $\begin{array}{c}83.32 \\
(64.56)\end{array}$ & $\begin{array}{l}673.98 \\
(67.93)\end{array}$ & $\begin{array}{c}2.95 \\
(0.95)\end{array}$ & $\begin{array}{c}4.15 \\
(2.38)\end{array}$ & $\begin{array}{l}95.06 \\
(3.16)\end{array}$ \\
\hline
\end{tabular}

\subsection{Result}

We run the one-way ANOVA analysis of comparing the levels of flow and game outcome variables between the students from online and F2F formats for the three BSGs. Table 4, 5 and 6 presents the result of the comparison between online and F2F students for the flow, game effort, and game performance in the three BSGs. The most noticeable findings from the analysis result is the average flow level of online students is significantly higher than that of F2F students throughout the three BSGs. Meanwhile, the levels of game effort of students in different formats are not significantly different except for BSG 3 in which online students put more effort than F2F students. Interestingly, as for game performance, F2F students outperform online students in BSG 1 and 2 whereas online students outperform F2F students in BSG 3.

Table 4. Analysis Result - BSG 1

\begin{tabular}{|c|c|c|c|c|}
\hline & \multicolumn{3}{|c|}{ BSG 1} \\
\hline & & Mean & $\mathrm{F}$ value & p-value \\
\hline \multirow{2}{*}{ Flow } & F2F & 2.89 & \multirow{2}{*}{17.110} & \multirow{2}{*}{$0.000^{* *}$} \\
\hline & Online & 3.47 & & \\
\hline \multirow{2}{*}{ Game Effort } & F2F & 74.04 & \multirow{2}{*}{0.134} & \multirow{2}{*}{$0.715^{\mathrm{ns}}$} \\
\hline & Online & 77.49 & & \\
\hline \multirow{2}{*}{$\begin{array}{c}\text { Game } \\
\text { Performance }\end{array}$} & $\mathrm{F} 2 \mathrm{~F}$ & 793.41 & \multirow{2}{*}{7.261} & \multirow{2}{*}{$0.008^{* *}$} \\
\hline & Online & 756.05 & & \\
\hline
\end{tabular}

*: significant at $\mathrm{p}=0.05, * *$ : significant at $\mathrm{p}=0.01$, ns: nonsignificant
Table 5. Analysis Result - BSG 2

\begin{tabular}{|c|c|c|c|c|}
\hline & \multicolumn{3}{|c|}{ BSG 2} \\
\hline & & Mean & F value & p-value \\
\hline \multirow{2}{*}{ Flow } & $\mathrm{F} 2 \mathrm{~F}$ & 2.75 & \multirow{2}{*}{24.160} & \multirow{2}{*}{$0.000^{* *}$} \\
\hline & Online & 3.44 & & \\
\hline \multirow{2}{*}{ Game Effort } & $\mathrm{F} 2 \mathrm{~F}$ & 86.17 & \multirow{2}{*}{0.997} & \multirow{2}{*}{$0.319^{\mathrm{ns}}$} \\
\hline & Online & 75.69 & & \\
\hline \multirow{2}{*}{$\begin{array}{c}\text { Game } \\
\text { Performance }\end{array}$} & $\mathrm{F} 2 \mathrm{~F}$ & 681.99 & \multirow{2}{*}{7.338} & \multirow{2}{*}{$0.007^{* *}$} \\
\hline & Online & 652.56 & & \\
\hline
\end{tabular}

*: significant at $\mathrm{p}=0.05, * *$ : significant at $\mathrm{p}=0.01$, ns: nonsignificant

Table 6. Analysis Result - BSG 3

\begin{tabular}{|c|c|c|c|c|}
\hline & & \multicolumn{3}{|c|}{ BSG 3} \\
\hline & & Mean & F value & $p$-value \\
\hline \multirow{2}{*}{ Flow } & $\mathrm{F} 2 \mathrm{~F}$ & 2.75 & \multirow{2}{*}{25.081} & \multirow{2}{*}{$0.000^{* *}$} \\
\hline & Online & 3.51 & & \\
\hline \multirow{2}{*}{ Game Effort } & $\mathrm{F} 2 \mathrm{~F}$ & 3.67 & \multirow{2}{*}{4.420} & \multirow{2}{*}{$0.038^{*}$} \\
\hline & Online & 4.69 & & \\
\hline \multirow{2}{*}{$\begin{array}{c}\text { Game } \\
\text { Performance }\end{array}$} & $\mathrm{F} 2 \mathrm{~F}$ & 94.44 & \multirow{2}{*}{21.602} & \multirow{2}{*}{$0.000^{* *}$} \\
\hline & Online & 96.71 & & \\
\hline
\end{tabular}

\section{Discussion and Conclusion}

As seen in the analysis result, there are significant differences that exist between online and F2F formats in the flow and game performance of BSG players. Meanwhile, little difference is found in game effort. These findings are discussed below. 


\subsection{Flow Perception}

The BSGs we used are a good learning vehicle and provided students with an opportunity to experience flow. We believe that these BSGs are a valid and practical way to study flow perception for a number of reasons. First, each BSG has a competitive component to it. Players can compare their game scores to their classmate's game scores and this motivates them to want to perform better. Second, each BSG, through the game playing process, provides sufficient and immediate feedbacks to the player in order to incrementally help the player improve their performance each time they play. Third, each BSG has a sufficiently complex game scenario that justifies the player's time commitment to play the game. More specifically, BSG 1 requires that students balance product scope, project schedules, and resource (cost) constraints, and a number of other parameters, and to execute a project plan that earns the highest number of performance related points in four areas, namely project scope, schedule, resources, and team processes. The goal of BSG 1 is to maximize overall performance points. On the other hand, BSG 2 requires students to balance demand and capacity under conditions of demand uncertainty so to maximize average nightly profitability in a restaurant. The goal of BSG 2 is to maximize average evening profit. In BSG 3 , students are required to integrate information and decisions from product design, production planning, and global sourcing, and are required to execute the plan, exposing the plan to a dynamic environment, and requiring the learner to make adjustments each period. The goal of BSG 3 is to maximize annual profit, as well as to maximize management performance assessment points as determined from the board of directors. Lastly, each BSG is a required exercise in a course and students earn course credit for playing the game. These particular (MBA) students tend to be competitive learners, striving to earn the maximum score in each game. As a result, we found students have experienced substantial degree of flow across the three BSGs regardless of the different formats as shown in Table 3.

We also found that the measurement items we used are useful to measure the flow experience across the three independent BSGs. Specifically we used three items corresponding to the three dimensions of flow among others suggested by Csikszwntmihalyi [11], namely, time distortion, concentration, and autotelic experience. We decided so mainly because the other dimensions of flow, such as clear goals, balanced challenge-skill level, immediate feedback, sense of control, action awareness merging, are rather preconditions of flow whereas the three dimensions we choose is the outcome factors of the flow experience as Chen [6] suggested earlier. Given that the main focus of this study is to compare the levels of flow experience while playing BSGs in different settings (i.e., online vs. F2F), we decide that focusing on the outcome dimensions of flow would serve better the research purpose.

From the ANOVA analysis, we observed that the level of perceived flow is significantly great for students in an online learning environment, in contrast to students in a F2F learning environment. As seen in the Table 4, 5, and 6, online students have higher levels of flow perception across the BSGs by at least 20 percent than F2F students. This result is consistent with a previous study that showed online learners scored higher engagement levels than F2F leaners [6]. We may explain this result by several ways that include computer dependency, available time on the computer, computer proficiency, and need for interactive learning. First, online students rely more on use of computer to succeed in the course. It is critical. The computer is, $100 \%$, their only window into the learning environment. F2F students have the campus experience, and their computer. It is likely that online students develop a great level of comfort with the computer, and also a greater sense of dependency on the computer. On more than one occasion we have heard the following (paraphrased) from on campus students "I work all day on the computer. The last thing I want is to be on the computer all night."

Second, if we assume that all students have the same amount of availability to dedicate to this MBA course, online students are spending more time online, whereas F2F students have in-class lectures and campus commute, and all its related inefficiencies, that place a demand on time available for learning.

Third, due to the above factors, online students likely have more proficiency regarding computer work. They are usually confident with using computers and mostly good at working in an independent environment. They are more self-learners and familiar with the computer-based, online learning format. Thus, they are more likely to get engaged in BSGs, which are computer-based and individually done, than F2F students.

Lastly, for online students, in-class interaction during their lectures is non-existent. Student learners naturally want to ask questions to validate existing information, to clarify existing information, or to solicit new information. The BSG is one effective means for interactive learning. Students can test or evaluate their information (decision making) and receive feedback that helps them fine-tune their information and their understanding. 
Another plausible explanation of high flow level in online environment is 'telepresence'. Telepresence is a perception of online users feeling that they are part of the action taking place online even though they are not physically with the others [41]. Telepresence has been used in many places to explain how people perceive and behave in online environments. Several research studies suggest that there is a relationship between flow and telepresence in virtual learning and gameplay [19][21][17]. Since the flow state experienced through BSGs would make online students lose consciousness of time and place during game playing, it would be more likely to make them feel telepresence which may in turn amplify flow perception. Because online students usually feel lack of interactions with instructor and/or course contents, the effect of BSGs on telepresence and flow in online learning could be higher than in F2F environment.

\subsection{Game Effort}

The analysis shows that there is not significant difference between online learners and F2F learners for BSG 1 and BSG 2, whereas a slight difference exists for BSG 3 (i.e., online learners put more effort into the game playing during BSG 3). This was somewhat contradictory to our initial hypothesis since we assumed that more flow experience would lead to more game effort in BSGs. We could explain this findings by the following points. First, all three BSG games have achievable, definitive goals. Unlike entertaining games such as Pokemon, or League of Legends, it is not likely that a player would play BSGs for unusually extended periods of time. So effort expended, for each player, may depend most on the players ability to achieve the specific goal that they seek. If a student is extremely bright, but only wants to earn a B, he/she will end up putting less effort in the game than the student who may struggle with understanding the game concepts, but who strives for an A. This is irrespective of whether the student in an online learner or a campus learner.

Second, BSG 3 is the most challenging of the three games and there is less time spent during the course to thoroughly review the Operations concepts inherent in the game. Since the measurement of game effort in BSG 3 was by the hours a student spent playing the BSG unlike the other BGSs (e.g., for BSG 1 and 2, game effort was measured by the number of runs a student played). It is likely that the online learners simply took longer to achieve their desired (individual) goal.

\subsection{Game Performance}

As shown in the analysis result, it turns out that F2F students outperform online students in two BSGs (i.e., BSG 1 and BSG 2). It is not only the flow perception but also many other aspects are needed to enhance the learning experience of BSGs. The two BSGs requires good understanding of specific concepts, such as triangle of project elements (i.e., resources, schedule, and scope) and trade-offs among them in Project Management, and throughput and process flow with batching in Service Operations Management. Even though those concepts are introduced in online course contents as well, the opportunity for ensuring and reinforcing the understanding of the concepts is relatively limited compared to F2F format. On-campus students can better leverage the camaraderie of their "MBA Cohort" in the BSG 1 and BSG 2 games. Sharing the winning game strategies \& tactics with fellow classmates is easier to do in BSG 1 and BSG 2. Online learners don't have the benefits of the cohort [sharing solutions with fellow classmate is strongly discouraged and is treated as plagiarism in both online and F2F environments. However, it is practically impossible to prevent all those practice in F2F setting.]

In addition, for these particular students, the students enrolled in the F2F format tended to have stronger quantitative \& analytics skills than the students enrolled in the Online environment. The differing levels of quantitative/analytic competency between students in the different formats might have contributed to the performance difference as well. This could be amplified in BSG 1 and 2, which require extensive quantitative analysis ability, because it is harder for online students to leverage the benefit of peers and instructors to learn quantitative techniques when they are isolated in an online environment.

Meanwhile, the BSG 3, online students outperform F2F students. BSG 3, Global Supply Chain Management game, encompasses much broader aspects of supply chain management and requires players to think more about integrated concepts of operations management than specific topics. This could be explained by the different level playing fields of BSGs. The benefits of being "book smart" is perhaps greatest in BSG 1 and BSG 2, where theory plays a larger role in determining successful strategies and tactics. BSG3 involves more integrative decision making and may be more conducive to entrepreneurial decision making (i.e., creative). It is possible that the playing field is more level.

Since BSG 3 is the last exercise of the semester, students playing BSG3 receive less instructions and insights regarding successful game strategies than the 
other games. On-campus students have less opportunity to leverage either their cohort, their quantitative \& analytics skills, and their classroom discussions.

Also, online students learn extensively through BSGs. Due to the limitations of interaction with instructor and peers, they learn the most through trialsand-errors in BSGs. For them, the BSGs are "THE" learning vehicle, whereas F2F students have a lot of alternative routes through which they learn, such as classroom learning or peer-to-peer learning. By accumulating the learnings from BSGs, online students could gain conceptual as well as technical knowledge of the subject at the end, which enables them to perform well at the last BSG of the course.

\subsection{General Takeaways}

The BSGs we used in this study are all different in their subject topics, focus, play methods, rules, and so on. Nonetheless, they each engage the student in a competitive game environment, and they each help students better understand difficult concepts.

The findings of this study provide several contributions to the business educators in higher education as well as trainers in practice who consider or already have implemented BSGs in online environment. We found that, in online environment, it is relatively easier to arouse flow state of learners by BSGs than F2F settings. Under the circumstances that many online business education programs struggle with engaging the students in learning experience, BSGs would be very effective way of solving the problem. By using BSGs, online business education programs can achieve both the students' engagement and satisfaction through flow.

However, the high flow does not always ensure the learners' effort and performance in BSGs as it is shown in the analysis of this study across the delivery formats. Rather we found that in an online environment, higher flow perception is not connected to more effort by the players. It might be because flow is not the only element that determine effort and performance in playing BSGs. To enhance the overall learning experience in online format using BSGs, more concerns and emphasis on making the learners understand the basic concepts and provide opportunities to interact with the instructor to ensure them to be ready to play the BSGs. This study would be an initial effort to explore the role of flow in the higher business education settings using BSGs. Based on the findings, future studies may be designed more accurately to articulate the impact of flow on learning.

Lastly, since our research design does not compare a BSG approach with a non-BSG approach, we cannot say yet, that a BSG approach results in greater flow than a non-BSG approach. But we do have endless qualitative observation that the BSGs engage the students. This is also confirmed by many previous studies of BSGs [20]. Moreover, it is especially true in online education environment. As more concerns and demands are gaining to develop better online business education methods to engage students, we are sure that BSGs can provide alternative learning vehicle in online business education where the traditional methods do not effectively engage the student any more.

\section{Limitations}

As with other studies, this study has some limitations. First, the data for analysis in this study was collected in a particular context, i.e., a Technology and Operations Management course in an MBA program. It is known that the quantitative area is one of the areas where BSGs are vigorously developed and widely used. Even though the result of this study is shown that there exist noticeable differences between online and F2F formats, it might be an overgeneralization to assume the findings to be applied to other areas. To expand the generalizability of the findings, future studies may include BSGs of various subjects.

Second, to measure the construct of flow, we used three items, which are mostly from the outcome dimensions of flow experience, such as time distortion, concentration, and autotelic experience [6]. However, there are more dimensions of flow, including clear goals, balanced challenge-skill level, immediate feedback, sense of control, action awareness merging [11]. In the future studies, it would be useful to include other dimensions of flow, which will provide a more comprehensive understanding of the flow in BSGs in online business education.

\section{References}

[1] AACSB International (2011). Globalization of Management Education: Changing International Structures, Adaptive Strategies, and the Impact on Institutions: Report of the AACSB International Globalization of Management Education Task Force. Bingley, UK: Emerald Group Publishing.

[2] Allen, I. E., \& Seaman, J. (2011). Going the distance: Online education in the United States, 2011. Wellesley, MA: Babson Survey Research Group.

[3] Arbaugh, J. B. (2014). System, scholar or students? Which most influences online MBA course effectiveness? Journal of Computer Assisted Learning, 30(4), 349-362.

[4] Beqiri, M. S., Chase, N. M., \& Bishka, A. (2010). Online course delivery: An empirical investigation of factors affecting student satisfaction. Journal of Education for Business, 85, 95-100. 
[5] Bressler, D. M., \& Bodzin, A. M. (2013). A mixed methods assessment of students' flow experiences during a mobile augmented reality science game. Journal of Computer Assisted Learning, 29(6), 505-517.

[6] Chen, H. (2006). Flow on the net-detecting Web users' positive affects and their flow states. Computers in Human Behavior, 222, 221-233.

[7] Chen, P. D, Gonyea, R., \& Kuh, G. (2008). Learning at a Distance: Engaged or Not? Innovate, 43.

[8] Cooper, K. (2010). Go with the flow: engagement factors for learning in Second Life. Proceedings of the 2010 Spring Simulation .... Society for Computer Simulation International.

[9] Cowley, B., Charles, D., Black, M., \& Hickey, R. (2008). Toward an understanding of flow in video games. Computers in Entertainment (CIE), 6(2), 20.

[10] Csikszentmihalyi, M. (1975). Beyond boredom and anxiety. San Francisco: Jossey-Bass.

[11] Csikszentmihalyi, M. (1991). Flow: The psychology of optimal experience. New York: HarperPerennial.

[12] Csikszentmihalyi, M. (1992). Optimal experience: Psychological studies of flow in consciousness. Cambridge university press.

[13] Csikszentmihalyi, M. (1997). Finding flow: The psychology of engagement with everyday life. New York: HarperCollins.

[14] Datar, S. M., \& Garvin, D. A. (2010). Rethinking the MBA: Business Education at aCrossroads. Boston, Mass.: Harvard Business Press.

[15] Dorn, D. S. (1989). Simulation games: One more tool on the pedagogical shelf. Teaching Sociology, 1-18.

[16] Drago, W., Peltier, J. W., \& Sorensen, D. (2002). Course content or instructor: Which is more important in online teaching? Management Research News, 25, 69-83.

[17] Draper, J. V., \& Blair, L. M. (1996). Workload, flow, and telepresence during teleoperation (Vol. 2, pp. 10301035). Presented at the IEEE International Conference on Robotics and Automation, IEEE.

[18] Egenfeldt-Nielsen, S. (2003, November). Review of the research on educational usage of games. Retrieved on March 31, 2014 from http://ibrarian.net/navon/paper/Review of the research on educational usage of ga.pdf?paperid $=1280105$

[19] Faiola, A., Newlon, C., Pfaff, M., \& Smyslova, O. (2013). Correlating the effects of flow and telepresence in virtual worlds: Enhancing our understanding of user behavior in game-based learning. Computers in Human Behavior, 29(3), 1113-1121.

[20] Faria, A. J., \& Wellington, W. J. (2004). A Survey of Simulation Game Users, Former-Users, and Never-Users. Simulation \& Gaming, 35(2), 178-207.

[21] Finneran, C. M., \& Zhang, P. (2003). A personartefact-task (PAT) model of flow antecedents in computermediated environments. International Journal of HumanComputer Studies, 59(4), 475-496.

[22] Garris, R., Ahlers, R., \& Driskell, J. E. (2002). Games, Motivation, and Learning: A Research and Practice Model. Simulation \& Gaming, 33(4), 441-467.

[23] Gee, J. P. (2003). What video games have to teach us about learning and literacy. New York, NY: Palgrave Macmillan.
[24] Gentry, J. W. (1990). What is experiential learning. Guide to Business Gaming and Experiential Learning, 9-20. [25] Hays, R. T. (2005). The Effectiveness of Instructional Games: A Literature Review and Discussion.

[26] Hoffman, B., \& Nadelson, L. (2010). Motivational engagement and video gaming: A mixed methods study. Educational Technology Research and Development, 58(3), 245-270.

[27] Hornik, S., \& Thornburg, S. (2010). Really Engaging Accounting: Second Life ${ }^{\mathrm{TM}}$ as a Learning Platform. Issues in Accounting Education, 25(3), 361-378.

[28] Hunter, H. (2013). Shift: Using Business Simulations and Serious Games: A straightforward guide for corporate training and development.

[29] Jones, K. O., \& Kelley, C. A. (2003). Teaching marketing via the Internet: Lessons learned and challenges met. Marketing Education Review, 13, 81-89.

[30] Jones, M. G. (1999). What Can We Learn from Computer Games: Strategies for Learner Involvement. In Proceedings of Selected Research and Development Papers Presented at the National Convention of the Association for Educational Communications and Technology [AECT], 21st, Houston, TX, February 10-14, 1999.

[31] Keys, B., \& Wells, R. A. (1989). Microtonics: an adventure in corporate management. John Wiley and Sons.

[32] Kiili, K. (2005). Content creation challenges and flow experience in educational games: The IT-Emperor case. The Internet and Higher Education, 8(3), 183-198.

[33] Knowles, M. S. (1970). The modern practice of adult education (Vol. 41). New York: New York Association Press.

[34] Konradt, U., Filip, R., \& Hoffmann, S. (2003). Flow experience and positive affect during hypermedia learning. British journal of educational technology, 34(3), 309-327.

[35] Lane, D. C. (1995). On a resurgence of management simulations and games. Journal of the Operational Research Society, 604-625.

[36] Lepper, M. R., \& Malone, T. W. (1987). Intrinsic motivation and instructional effectiveness in computer-based education. In R. E. Snow \& M. J. Farr (Eds.), Aptitude, learning, and instruction volume 3: Conative and affective process analyses (pp. 255-286). Hillsdale, NJ: Lawrence Erlbaum Associates, Publishers.

[37] Malone, T. (1981). Toward a theory of intrinsically motivating instruction. Cognitive Science, 5(4), 333-369.

[38] Massimini, F. \& Carli, M. (1990). Systematic assessment of flow in daily experience. In Flow: The Psychology of Optimal Experience. Harper and Row, New York.

[39] Michael, D. R., \& Chen, S. L. (2006). Serious Games: Games That Educate, Train, and Inform. Boston, MA: Thomson Course Technology.

[40] Mitchell, R.G., Jr. (1990). Sociological implications of the flow experience. In Flow: The Psychology of Optimal Experience. Harper and Row, New York.

[41] Novak, T., Hoffman, D., \& Yung, Y. (2000). Measuring the customer experience in online environments: A structural modeling approach. Marketing Science, 19(1), 22-42.

[42] Park, J., Parsons, D., \& Ryu, H. (2010). To Flow and Not to Freeze: Applying Flow Experience to Mobile 
Learning. IEEE Transactions on Learning Technologies, $3(1), 56-67$.

[43] Parker, L. E., \& Lepper, M. R. (1992). Effects of fantasy contexts on children's learning and motivation: Making learning more fun. Journal of Personality and Social Psychology, 62(4), 625-633.

[44] Peltier, J. W., Schibrowsky, J. A., \& Drago, W. (2007). The interdependence of the factors influencing the perceived quality of the online learning experience: A causal model. Journal of Marketing Education, 29, 140-153.

[45] Prensky, M. (2001). Digital Game-Based Learning, New York: McGraw-Hill.

[46] Rathunde, K. (1990). Optimal experience and the family context. In Flow: The Psychology of Optimal Experience. Harper and Row, New York.

[47] Rathunde, K., \& Csikszentmihalyi, M. (2005). Middle school students' motivation and quality of experience: A comparison of Montessori and traditional school environments. American journal of education, 111(3), 341371.

[48] Rieber, L. P. (1996). Seriously considering play: Designing interactive learning environments based on the blending of microworlds, simulations, and games. Multiple Values Selected, 44(2), 43-58.

[49] Riedel, J. C., \& Hauge, J. B. (2011, June). State of the art of serious games for business and industry. In Concurrent Enterprising (ICE), 2011 17th International Conference on (pp. 1-8). IEEE.

[50] Rupp, A. A., Gushta, M., Mislevy, R. J., \& Shaffer, D. W. (2010). Evidence-centered design of epistemic games: Measurement principles for complex learning environments. The Journal of Technology, Learning and Assessment, 8(4).

[51] Sato, I. (1990). Bosozkou: Flow in motorcycle gangs. In Flow: The Psychology of Optimal Experience. Harper and Row, New York.

[52] Sebastianelli, R., Swift, C., \& Tamimi, N. (2015). Factors Affecting Perceived Learning, Satisfaction, and Quality in the Online MBA: A Structural Equation Modeling Approach. Journal of Education for Business, 90(6), 296305.

[53] Shernoff, D. J., Csikszentmihalyi, M., Schneider, B., \& Shernoff, E. S. (2003). Student engagement in high school classrooms from the perspective of flow theory. School Psychology Quarterly, 18, 158e176.

[54] Wallace, R. M. (2004). A framework for understanding teaching with the Internet. American Education Research Journal, 41, 447-489.

[55] Wolfe, J. (1993). A History of Business Teaching Games in English-Speaking and Post-Socialist Countries: The Origination and Diffusion of a Management Education and Development Technology. Simulation \& Gaming, 24(4), 446-463.

\section{Appendix - BSG Screenshots}

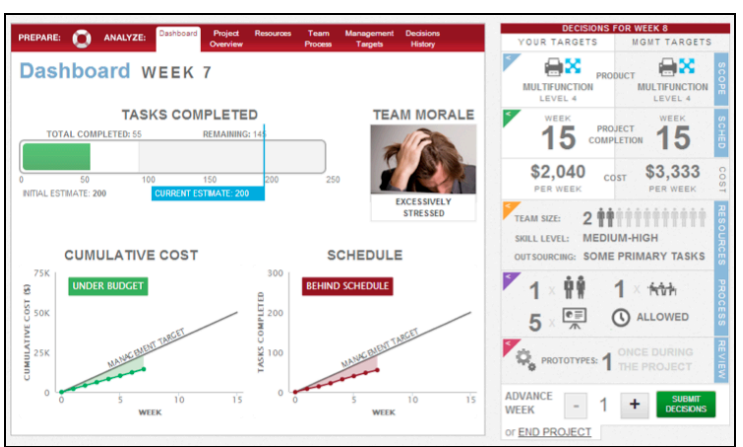

Figure A-1. BSG 1 (Project Management) Screenshot

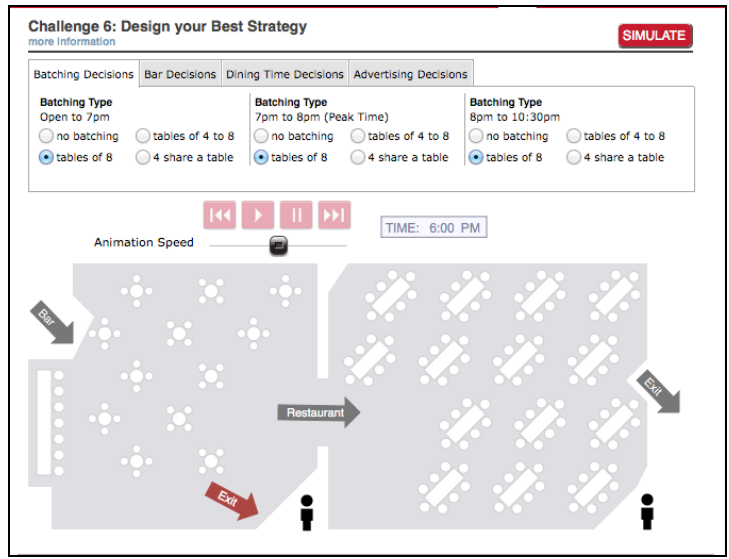

Figure A-2. BSG 2 (Service Operations Management) Screenshot

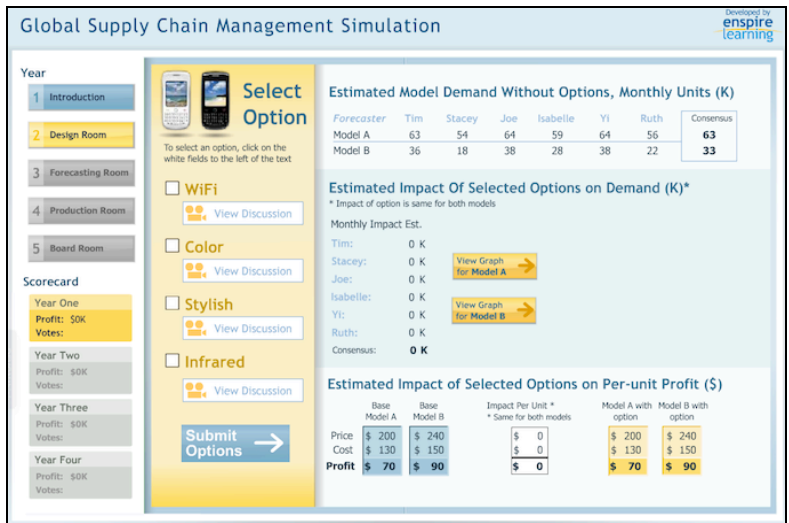

Figure A-3. BSG 3 (Global Supply Chain Management) Screenshot

Screenshot source - https://cb.hbsp.harvard.edu 